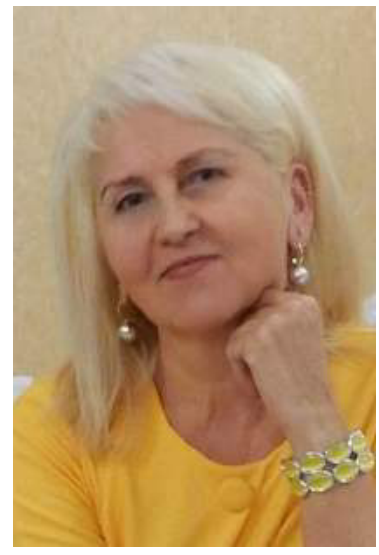

Ірина Розман,

кандидат педагогічних наук, доцент кафедри філологічних дисциплін та соціальних комунікацій, Мукачівський державний університет (м. Мукачево, Україна)

\section{Iryna Rozman,}

Candidate of Pedagogical Sciences, Associate Professor, Department of Philological Disciplines and Social Communications, Mukachevo State University (Mukachevo, Ukraine) rozmanii@ukr.net ORCID ID 0000000249510074

Удк 37.0112 (477)

\title{
ДІАЛЕКТНЕ СЕРЕДОВИЩЕ ЗАКАРПАТТЯ ТА ЙОГО ВПЛИВ НА КУЛЬТУРУ МОВЛЕННЯ МАЙБУТНІХ ПЕДАГОГІВ
}

Анотація. У статті акцентується увага на сучасних вимогах до професійної підготовки майбутніх педагогів, які ставлять перед закладами вищої освіти, одним із яких є процес формування культури мовлення студентів. Мета статті - висвітлити теоретичні аспекти процесу формування культури мовлення майбутнього вчителя за умов діалектного середовища Закарпаття, показати вплив діалектного середовища регіону на мовленнєву культуру студентів. Проаналізовано питання формування в майбутніх учителів початкової школи культури професійного мовлення на засадах компетентнісного підходу; увиразнено комунікативні якості професійного мовлення педагога. Порушену проблему розглянуто в таких аспектах: нормативність, адекватність, естетичність, поліфункціональність мовлення. Основні комунікативні якості культури професійного мовлення вчителя - змістовність, доречність, доступність, правильність, чистота, точність, логічність, багатство, виразність.

Досліджено проблему впливу діалектного середовища Закарпаття на культуру мовлення майбутнього педагога. У спілкуванні студенти використовують діалектні слова, тому що їхня мова близька до мови мешканців тих населених пунктів, де вони мешкали до вступу до вишу; мовлення студентів міської місцевості містить змішані діалектизми внаслідок взаємодії двох мов - української й російської, а також так званої русинської мови; у мовленні студентів наявні жаргонні слова. Закарпаття - це багатоетнічний регіон, у якому мешкають понад 70 етнічних груп.

Ключові слова: культура мовлення, Закарпаття, діалектне середовище, діалекти, культура спілкування.

\section{DIALECT ENVIRONMENT OF TRANSCARPATHIA AND ITS IMPACT ON THE FUTURE TEACHERS' SPEECH CULTURE}

\begin{abstract}
The article focuses on modern requirements for professional training of future teachers that set tasks for the higher institution of education one of which is formation of students' speech culture. The aim of the article is to highlight theoretical aspects of the process of forming the speech culture of a future teacher in the conditions of the dialectal environment of Transcarpathia, to show influence of the dialectal environment of the region on the students' speech culture.

The issues of forming the future primary school teachers' professional speech culture based on the competence approach are analyzed; the communicative qualities of the teacher's professional speech are clarified.

Possession of culture of the professional speech means assimilation of professionally focused synthesis of grammatical norms and options of word usage, the syntactic organization of the phrase which provides the language (oral and written) registration of process and results of work in professional activity. Main communicative qualities of the professional speech of the teacher are as follows: meaningfulness, relevance, intelligibility, correctness, purity, accuracy, logic, and richness, expressiveness.

In the article, the problem of education communication culture of schoolchildren in multiethnic environment is examined. The author highlights certain aspects of formation of speech culture among students, emphasizing the system of communicative indicators, among which correct and flawless speech are essential ones. Transcarpathia is a multi-ethnic region which is home to over 70 ethnic groups. Minorities are marked off by a high level of linguistic sustainability. A powerful center that promotes preservation of national traditions and minority languages is the educational institution. In the Transcarpathian region there are public and private secondary schools with different languages of instruction. Transcarpathia is a multinational region where many cultures, traditions, customs and languages operate. Therefore, this region is interesting and promising for research. The authors foreground the aspects which deserve attention in order to avoid possible inconveniences in communication and introduce needful measures for improving professional training of the future teachers.

Keywords: the culture of speech, multi-ethnic environment, education, culture, communication, international communication.
\end{abstract}




\section{ВСТУП}

Постановка проблеми. Культура мовлення кожної людини виявляється і формується в процесі спілкування. Якість мовного спілкування залежить від багатьох чинників, пов'язаних і з психологічними особливостями мовців, і з ситуативністю процесу мовлення. Мовне спілкування студентів залежить від місця, умов проживання, виховання у дошкільний та навчання в шкільний періоди; у ньому відбиваються вікові особливості реципієнтів, їхні інтереси, уподобання. Мова студентів формується загалом під впливом таких чинників: особливостей мови мешканців історико-етнографічних регіонів України, де мешкав студент до вступу до ВН3; нових умов життя, навчання, побуту юнацтва, яке навчається у виші; специфіки майбутнього фаху тощо.

Важливим чинником впливу на формування культури мовлення студентів є мовне середовище, у якому вони перебували до вступу до вишу, тобто діалектне середовище. Більшість студентів мешкає в сільській місцевості, зокрема Закарпаття. Закономірно, що в їхньому спілкуванні відбиваються регіональні особливості мови, пов'язані передусім з характером господарської діяльності місцевого населення, тобто закарпатська говірка.

Аналіз останніх досліджень і публікацій. В українському мовознавстві ведуться активні дослідження, спрямовані на розв'язання багатьох проблем діалектології. 3-поміж актуальних залишаються питання комплексного вивчення всіх мовних рівнів говорів, які досліджували П. Гриценко (змінність / стабільність діалектної мови), В. Ващенко (сурогатні творення в процесі міждіалектних контактів), В. Ґрещук (проблеми використання гуцульської говірки в художніх творах), В. Ґрещук (використання гуцульської говірки в белетристичних, художніх творах; методика вивчення діалектизмів у школі), А. Залеський (діалектне розмаїття української мови), В. Кононенко (гуцульська говірка в художніх текстах), І. Матвіяс (говори української мови) та ін. Ці та інші праці [1-10] певним чином є орієнтиром у визначенні шляхів удосконалення культури мовлення особистості, однак у сучасній науці немає окремого дослідження, у якому б ішлося про фрормування культури мовлення майбутнього педагога за умов діалектного середовища Закарпаття.

МЕТА І ЗАВДАННЯ ДОСЛІДЖЕННЯ - проаналізувати вплив діалектного середовища Закарпаття на мовленнєву культуру майбутніх педагогів.

МЕТОДИ ДОсЛІДЖЕНнЯ: у процесі дослідження використано теоретичні та емпіричні методи: теоретичні - вивчення праць 3 актуальних проблем викладання української мови у вищих навчальних закладах; критичний аналіз української лінгвістичної та методичної літератури; емпіричні - анкетування студентів з метою виявлення рівня їхнього мовленнєвого досвіду та створення передумов для формування умінь і навичок нормативного мовлення; педагогічний експеримент; кількісний та якісний аналіз експериментальних даних.

\section{РЕЗУЛЬТАТИ ДОСЛІДЖЕННЯ}

Ураховуючи вплив усної форми на писемну, вважаємо, що формування культури мовлення майбутніх педагогів треба починати з удосконалення усних мовленнєвих навичок, і тим самим запобігати виникненню недоліків діалектного характеру в писемному мовленні.У нашому дослідженні йдеться про здатність конкретної групи мовців користуватися мовою в практичній діяльності, тому в подальшому викладі послуговуватимемося терміном «культура мовлення» і розглядатимемо її як засіб підготовки майбутнього вчителя.

Аналіз трактувань ученими поняття «культура мовлення» (Н. Бабич, Б. Головін, М. Ілляш, М. Пентилюк, О. Пономарів, ін.) дає підстави для висновку: культура мовлення має теоретичний і практичний аспекти. Спираючись на відомі в мовознавстві твердження, культуру мовлення майбутнього педагога визначаємо як володіння унормованим літературним мовленням в усній і писемній формах на всіх мовних рівнях, здатність використовувати мовні засоби, оптимальні для конкретної ситуації мовлення. Центральним поняттям культури мовлення є мовна норма. Дотримання чи порушення мовних норм слугує найважливішим критерієм оцінки висловлювань.

Ураховуючи фонетичні, морфологічні й лексичні особливості закарпатських говорів, діалектизми, виявлені в мовленні студентів, ми розподілили за групами і з'ясували, що їх роль у процесі спілкування може бути різною. Так, фонетичні діалектизми є зрозумілими всім мовцям, котрі спілкуються між собою, незалежно від специфіки мови регіонів, де вони мешкали до початку навчання у ВНЗ. Лексичні ж діалектизми ускладнюють комунікацію, бо $є$ незрозумілими для тих, хто розмовляє іншим діалектом або літературною мовою. Використання студентами діалектних слів є закономірним явищем, бо саме через цю лексику простежується тісний зв'язок з історією, побутом, звичаями рідного краю. Кожна освічена людина повинна добре знати і пам'ятати назви понять, явищ, предметів народного вжитку, характерних для місцевості, де вона народилася і зросла. Така лексика не заважає спілкуванню з людьми, які розмовляють тим же діалектом, а значно збагачує людину, її світогляд, підвищує культуру загалом.

До діалектних слів, уживаних у мові майбутніх учителів, ми віднесли також і суржикові (більйо, стірка, мусор, утюг, юбка, грузчик, стаканчик тощо). На так званих суржикових особливостях мовлення студентів слід зупинитися окремо, оскільки саме такі слова й словосполучення є змішаними діалектизмами, притаманними мешканцям міста (з-поміж студентів мешканців сільської місцевості загалом 82 \% , міських - 18 \%).

Активне наростання сурогатних творень спостережено в середовищі змішаного мовлення. Такі явища спричинили витворення своєрідного різновиду мови, який дістав назву «суржик». Мішаниною двох мов- 
української та російської - говорить частина людності України (і Закарпаття, як виявилося, не є винятком), хоч загальновизнано, що користування сумішшю з двох мов - одне з найтривожніших явищ.

В. Ващенко порушує питання про те, що в говорах переселенських етнічних груп білінгвізм створює ряд специфічних явищ: порушення фонетичної, граматичної та синтаксичної упорядкованості (отвічаю, у рукі, дякую вас, не був по хворобі, по завданню, глузувати над ним). Це так звані «перехідні говірки», а точніше - явища сурогатного типу [5, с. 140-142].

Більшість мовознавців (І. Білодід, В. Ващенко, Ю. Жлуктенко та ін.) відзначають негативний вплив сурогатних творень на культуру мовлення [7, с. 149]. Білінгвізм майже завжди супроводжується явищем інтерференції, яка може зустрічатися на різних мовних рівнях. У визначенні цього явища мовознавцями одностайності не виробилося. Ю. Жлуктенко інтерференцією вважає всі зміни в структурі мови, що виникають як наслідок її взаємодії з іншою мовою в ситуації мовного контакту [5, с. 141]. Такої ж думки про закони розвитку контактуючих мов дотримується О. Сербенська. У неї не викликає заперечень той природний процес, коли людина вводить у своє мовлення слова і словосполуки іншої мови, не руйнуючи граматичної основи, фонетичних особливостей української, оберігає її красу, користується її невичерпним лексичним і фразеологічним багатством. Однак, довільно змішуючи слова української та російської мов, відмінюючи слова і сполучаючи їх за зразком російської, творячи фррази всупереч моделям рідної мови, її носій мимоволі стає «напівмовним», приймає мовний покруч [1, с. 9].

Ми схиляємося до думки, що наявність суржикових слів у мовленні майбутніх фахівців - явище негативне, оскільки скалічена мова отупляє людину, робить ії мислення примітивним, адже мова виражає не тільки думку слово стимулює свідомість, підпорядковує її собі. Звідси випливає необхідність усунення суржику як змішаного діалекту з мовлення студентів, метою яких є досягнення мовленнєвої майстерності. У мові юнаків та дівчат, котрі здобули статус студента, у зв'язку з залученням до навчального процесу, студентського побуту з'являються слова, що в мовознавстві дістали назву жаргону - соціального різновиду мовлення, котрий характеризується вузькопрофесійною, часом експресивно переосмисленою лексикою та фразеологією загальнонародної мови. Жаргон фрормується у групах людей, об'єднаних спільністю інтересів, звичок, занять. Він загалом відштовхується від загальнолітературної мови і є, на думку С. Бевзенка [3, с. 13], соціальним діалектом певної вікової спільності. Такий жаргон має назву студентського, він $є$ основою молодіжного сленгу.

Науковець С. Мартос, досліджуючи сленг як об'єкт соціолінгвістики, стверджує, що молодіжний сленг - це соціальний діалект, він є частиною української мови і безперервно взаємодіє з іншими сленгами, літературною мовою та її діалектами. Соціальні діалекти не можна залишати поза увагою, їх вивчення має велике значення не тільки для теоретичних досліджень у галузі мовознавства, а й для практичного розв'язання питань культури мовлення [8, с. 51-52].

У мові студентів ми виявили соціальні діалектизми - студентський жаргон. До його арготичної частини можна віднести слова пара, ботанік, зачотка, комп, шпори, ас, діскарь, общага, курсач та ін. Це здебільшого назви предметів, посад, приміщень, які використовуються для організації навчально-виховного процесу, відпочинку студентів. До складу їхнього загальнопобутового словника належать слова прикол, грузити, валити, тусовка, підстава, западло, качок, штемп, крутий, бакси. Остання група жаргонних слів означає поняття та предмети, з якими студенти стикаються щоденно як у процесі навчання, так і в позанавчальний час у спілкуванні зі своїми ровесниками.

Жаргонна лексика, на відміну від територіальних діалектів, зазвичай довго залишається у словниковому складі студентів, здебільшого до кінця їхнього навчання у виші. Ми вважаємо, що жаргонна лексика знижує рівень культури мовлення майбутніх педагогів, засмічує мовлення студентів; ії̈ (як продукт соціального діалекту) необхідно усувати з мовлення майбутніх фахівців, з іншого боку, така лексика надає емоційної експресивності мовленню її носіїв, слугує гумористичному характеру висловлюваного.

Загалом словниковий склад студентів різноманітний за семантикою, стильовими різновидами, містить територіальні, змішані й соціальні діалектизми, оскільки відображає умови їхнього життя, навчання, виховання в шкільний період та під час перебування в університеті.

У мовознавстві немає одностайності в поглядах на побутування діалектизмів у мовленні носіїв мови. Слушною, зокрема, є думка вченого А. Очеретного, який уважає, що діалектні особливості мовлення часто створюють серйозні перешкоди засвоєнню норм літературної мови. Відмінне від літературної мови фронетичне або морфологічне оформлення окремих слів, а також уживання деяких слів і сполук, так званих діалектизмів, впливають на рівень культури мовця [9, с. 40]. Цікавими є міркування російських учених. Так, досліджуючи норми сучасної російської мови, К. Горбачевич стверджує, що територіальні діалекти не відіграють значної ролі в утворенні норм літературної мови, але деякі особливості діалектного мовлення дуже стійкі. Першочергове завдання навчального закладу, на думку вченого, - це «усунення засвоєних у ранньому дитинстві діалектних рис вимови, котрі нерідко зумовлюють орфографічну малограмотність учнів» [цит. за: 3, с.12]. Ми цілком поділяємо цю думку вченого.

Отож урахування особливостей місцевих говірок має важливе значення в удосконаленні орфографічної грамотності студентів, оскільки діалектні орфографічні помилки, як зазначає учений А. Текучов, «дуже численні і різноманітні за своїм характером і ... вимагають особливого до них методичного підходу» [11, с. 3]. Порушуючи питання, як повинен оцінювати виш діалектні особливості (ставитися до них терпимо, вважаючи, що вони певною мірою природні для студента, який зростав у селі, чи оголосити їм непримиренну боротьбу), А. Текучов 
відповідає на нього так: «Учитель зобов'язаний розглядати діалекти як явище небажане, а в більшості випадків і недопустиме» [11, с. 12].

Нам більше імпонує позиція Н. Бабич, І. Фаріон та інших мовознавців і методистів, які не так категорично ставляться до діалектних особливостей мовців. Н. Бабич, зокрема, зазначаючи, що фундаментом мовної майстерності є літературна мова, радить не ігнорувати діалектне мовлення, соціально-діалектні його особливості, бо саме тут «може виникнути підстава для перегляду діючих правил, норм таїх функціонально-стильових варіантів» [2, с. 70]. Дослідники Л. Паламар і Г. Кацавець застерігають від надмірного вживання діалектної лексики: це ускладнює сприйняття висловлювання чи тексту. Діалектну лексику треба використовувати, але обережно, «дбати про те, щоб вона не засмічувала мову і не утруднювала сприймання творів читачами» [10, с. 21].

Зважаючи на ці твердження, вважаємо, що викладач повинен глибоко вивчити діалектні риси регіону, у якому працює, щоб виправляти відхилення від літературної норми, найтиповіші для певної говірки. Для цього необхідно звернутися до праць відомих діалектологів, що досліджували особливості мовлення населення певної території, і методистів, які на основі цих досліджень розробляли методику формування грамотного письма й правильного усного літературного мовлення.

\section{ВИСНОВКИ ТА ПЕРСПЕКТИВИ ПОДАЛЬШИХ ДОСЛІДЖЕНЬ}

Отже, діалектне середовище активно впливає на формування мовної особистості студента взагалі й рівень його мовленнєвої культури зокрема, оскільки: словник відображає особливості мови мешканців сільської місцевості, а тому містить слова, пов'язані з сільськогосподарським виробництвом; у спілкуванні студентами використовуються діалектні слова, тому що їхня мова близька до мови мешканців тих населених пунктів, де вони проживали до вступу до вишу; мовлення студентів міської місцевості містить змішані діалектизми внаслідок взаємодії двох мов - української й російської, а також так званої русинської мови; у мовленні студентів наявні жаргонні слова, що існують для найменувань понять, пов'язаних із особливостями навчального процесу, умовами студентського побуту в результаті спілкування мовців, однакових за віком, близьких за інтересами; у спілкуванні між собою та 3 викладачами студенти використовують спеціальну лексику - терміни, пов'язані з майбутнім фахом.

Для успішного розв'язання проблеми фрормування культури мовлення студентів - майбутніх педагогів - за умов закарпатського говору необхідно окреслити шляхи подолання мовленнєвих недоліків діалектного характеру визначити лінгводидактичні засади фрормування мовленнєвих умінь і навичок студентів, тобто принципи, методи і прийоми навчання мови у виші. Цей аспект може стати предметом подальших досліджень.

\section{СПИСОК ВИКОРИСТАНИХ ДЖЕРЕЛ}

[1] Антисуржик / За ред. О. Сербенської. Львів, 1994. 152 с.

[2] Бабич Н. Д. Основи культури мовлення. Львів, 1990. 380 с.

[3] Бевзенко С. П. Українська діалектологія. Київ, 1980. 248 с.

[4] Білавич Г. Діалектне розмаїття Карпатського краю. Івано-Франківськ, 2014. 115 с.

[5] Ващенко В.С. Про сурогатні творення в процесі міжмовних (міждіалектних) контактів. Говори і ономастика Наддніпрянщини. Дніпропетровськ, 1970. С. 140-152.

[6] Дослідження з української діалектології: Збірник наук. праць / Відп. ред. П. Ю. Гриценко. Київ, 1991. 261 с.

[7] Закономірності розвитку українського усного літературного мовлення / Під ред. І. К. Білодіда. Київ, 1965.312 с.

[8] Мартос С. Сленг як об'єкт соціолінгвістичних досліджень. Збірник наук. праць «Південний архів». Херсон, 1999. Вип. 5. С. 46-52.

[9] Очеретний А. Д. Подолання впливу перехідних говірок у навчанні української літературної мови. Дивослово. 1997. № 7. С. $40-45$.

[10] Паламар Л. М. Українське ділове мовлення. Київ, 1997. 296 с.

[11] Текучёв А. В. Основы методики орфографии в условиях местного диалекта. Москва, 1953. 183 с.

\section{REFERENCES (TRANSLATED AND TRANSLITERATED)}

[1] Antysurzhyk (Antifreeze). Zared.O. Serbens'koyi. L'viv, 1994. P. 152. (in Ukrainian)

[2] Babych N. D. Osnovy kul'tury movlennya (The basis of the culture of speech). L'viv, 1990. P. 380. (in Ukrainian)

[3] Bevzenko S. P. Ukrayins'ka dialektolohiya (Ukrainian dialectology). Kyiv, 1980. P. 248. (in Ukrainian)

[4] Bilavych H. Dialektne rozmaittia Karpatskoho kraiu (The dialectal diversity of the Carpathian region). Ivano-Frankivsk, 2013. Pp. 259-269. (in Ukrainian)

[5] Vashchenko V. S. Pro surohatni tvorennya v protsesi mizhmovnykh (mizhdialektnykh) kontaktiv (About surrogate creation in th eprocess of interlingual (interstitial) contacts). Hovory i onomastyka Naddnipryanshchyny. Dnipropetrovs'k, 1970. Pp. 140-152. (in Ukrainian)

[6] Doslidzhennya z ukrayins'koyi dialektolohiyi (Researchon Ukrainian dialectology). Zbirnyknauk. prats'. Kyiv, 1991. P. 261. (in Ukrainian)

[7] Zakonomirnosti rozvytku ukrayins'koho usnoho literaturnoho movlennya (Patterns of development of Ukrainian oral literary speech). Kyiv, 1965. P. 312. (in Ukrainian)

[8] Martos S. Slenh yak obyekt sotsiolinhvistychnykh doslidzhen' (Slang as an object of sociolinguistic research). Zbirnyk nauk. prats' "Pivdennyy arkhiv". Kherson, 1999, Vol. 5. Pp. 46-52. (in Ukrainian)

[9] Ocheretnyy A. D. Podolannya vplyvu perekhidnykh hovirok u navchanni ukrayins'koyi literaturnoyi movy (Overcoming the influence of transitional dialects in the teaching of the Ukrainian literary language). Dyvoslovo, 1997. Vol. 7. Pp.40-45. (in Ukrainian)

[10] Palamar L. M. Ukrayins'ke dilove movlennya (Ukrainian business broadcasting). Kyiv, 1997. P. 296. (in Ukrainian)

[11] Tekuchëv A. V. Osnovy metodyky orfohrafyy $\vee$ uslovyyakh mestnoho dyalekta (Fundamentals of the technique of spellingin a local dialect). Moskva, 1953. P. 183. (in Russian) 